\title{
Evasion in Police-Suspect Interrogating Discourse: \\ A Discourse Analytic Study of the Transcript of the Interrogation of Anthony Sowell
}

* Dr. Hanaa Mohamed Hilmy El-Gindy

\begin{abstract}
This research paper attempts to study evasion in police- suspect interrogating discourse. It selects the transcript of the interrogation of Anthony Sowell as its data for analysis. It shows that evasion exists only in conversational discourse that is mainly based on question- answer sequences. And in most of the cases, it is intentional. So, a discourse analytic approach is appropriate. In the case of this research, the police officers interrogate Anthony Sowell, a real serial killer, to get confessions from him about his crimes. But Anthony does his best to offer them evasive answers. His cunningness lies in his ability to afford answers which are semantically irrelevant and pragmatically coherent at the same time. He pretends to be cooperative whereas in fact he is not. The framework of this research is two- fold. It studies evasion and the detection of evasion through questioning. On one hand, it works on the level of evasion from the part of the suspect. It shows that the evasive answers of the suspects are covert and overt. And on the other hand, it inspects the detection of evasion through questioning by the police interrogators. Regarding covert evasion, the research applies a theoretical framework that studies it from the following three perspectives: 1) changing the textual context of the question; 2) changing the focus of the question; and 3) changing the focus and the textual context of the question (Galasinski, 2000). And concerning overt evasion, the theoretical framework focuses on 'opting out'. The research shows that evasion with its two types is deceiving because on the surface, the suspect seems cooperative, but underneath, he is not. As for the detection of evasion, the theoretical framework of this research spots light on the interviewers' reactions towards this evasion. It uses 'contingent questions', 'presupposition triggers' and 'next questions' as frameworks for the detection of evasion. Two types of contingent questions are discussed: 'and- and so- prefacing questions. The research condudes that the conflict between interrogators and suspects is endless. Interrogators still need to exert more effort to be able to elicit true information and detect evasion during their cross interrogation of the suspects.
\end{abstract}

Key Words: Evasion; discourse analysis; police- suspect interrogating discourse; covert evasion; overt evasion; and the detection of evasion.

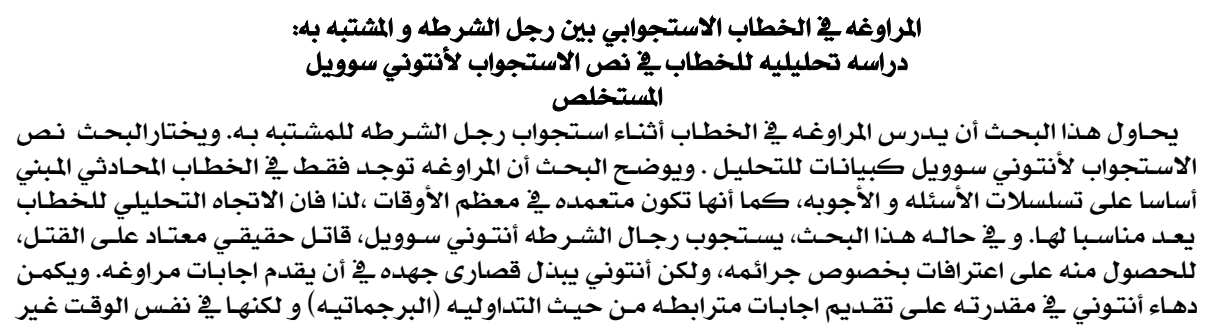

* Lecturer of Linguistics - Dept.of Foreign Languages - Faculty of Education Mansoura University. 


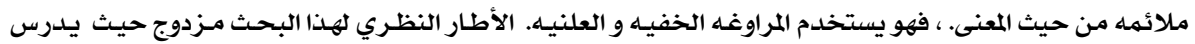

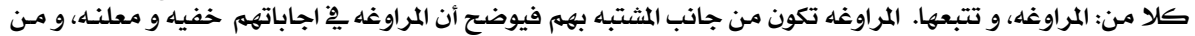

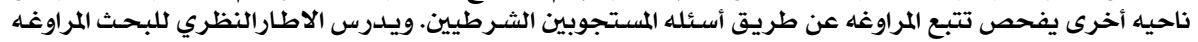

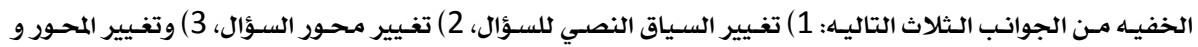

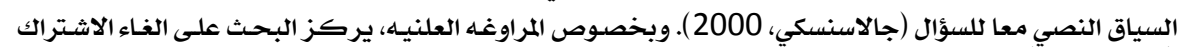

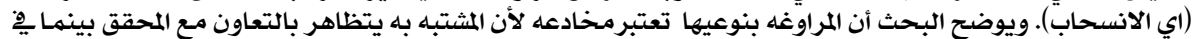

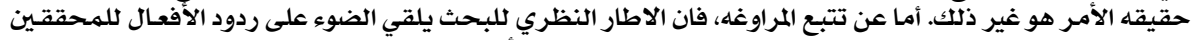

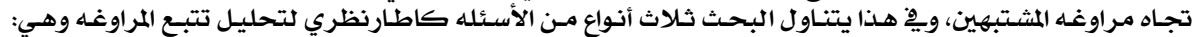

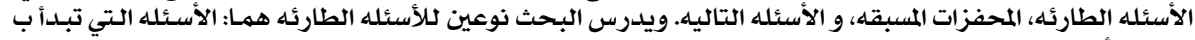

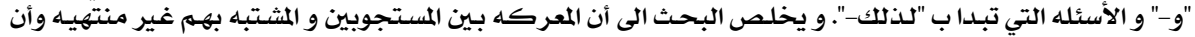

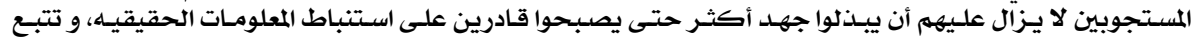

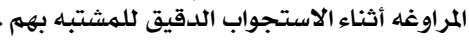

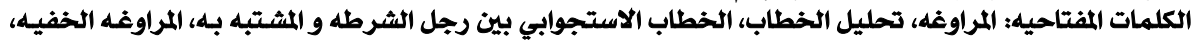

\section{I.Introduction:}

المراوغه المعلنه، تتبع المراوغهاته.

This research attempts to study evasion in police-suspect interrogating discourse. It emphasizes the role of language in affirming or denying charges that may seriously affect the future life of the suspects. It offers a discourse analytic study of the transcript of the interrogation of Anthony Sowell. In so doing, it highlights the use of language in real interrogations about real crimes rather than its structure. It shows how language is used by police officers to elicit confessions from suspects and how suspects use it to evade and deny criminal allegations attributed to them. Interrogators seem more powerful than their suspects, as they are the ones who ask the questions, allocate turns and are able to detain them. However, suspects do not always cooperate with police interrogators. They do not tell the whole truth all the time. They usually lie, deceive and give evasive answers in order to safe guard themselves from saying utterances that may be used against them later on in courtrooms. As for the data for analysis, the researcher selects real data about a serial women killer in U.S.A. called Anthony Sowell. He is known as the Cleveland Strangler. The transcript of his interrogation is life. It is tape and video recorded and this sustains the credibility of the interrogations. The researcher offers a transcription of the data according to Jail Jefferson's model.

Many researches have been done on coercion and power in policesuspect interrogations (Fowler, et al., 1079; Greatbatch, 1986; Drew and Heritage,eds., 1992; and Stokoe, 2010: 60). They mainly concentrated on police officers as representatives of authority against their obliterated suspects. They have conducted their analysis from a conversation analytic point of view that focused primarily on the interactional asymmetry 
between the interviewers and the interviewees. Wodak (1995: 204) stated that they concentrated on "structural relationships of dominance, discrimination, power and control as manifested in language". But they did not tackle evasion from the part of the suspects to escape from the heavy pressure of questioning during interrogation. And this is the goal of this research. It studies evasion in police-suspect interrogation from a discourse analytic perspective. Scollon and Scollon (2003: 2) pinpointed the link between discourse and meaning in context. They claimed that discourse analysis in the twenty- first century focuses on "the study of the social meanings of the material placement of signs and discourses and of our actions in the material world". According to them, social discourse and the situational context in which the utterances are produced are interrelated. In police- suspect interrogations, the situational context which is the interrogating room in this context plays a very important role in the trajectory of interrogation.

\section{The Stages of Police Interaction with Suspects:}

Police- suspect interaction represents an instance of institutional discourse. In fact, the mere presence of some participants in interaction in specific settings imposes a special kind of relationship between them. They become subjects to the "frames" (Goffman, 1981) that their professions allocate to them. They have to follow the specific kind of agenda that fits their roles in this institution. Drew and Heritage (1992: 34) point out that "interaction is institutional insofar as participants' institutional or professional identities are somehow made relevant to the work activities in which they are engaged". Police- suspect interaction seems similar to doctor- patient interaction as they both share the same objective of seeking information from their targets. However, they are not totally identical. Doctors elicit "life- world information" (Mishler, 1984) from patients to help them ride a better healthier life. In so doing, doctorpatient interaction is characterized by asymmetry in interaction. On the other hand, police interrogators seek information to obtain evidence or confession from their suspects. Gibbons (2003: 95) identifies two functions of questions in legal contexts: firstly, eliciting information about a particular event; and secondly, obtaining confirmation of a specific 
version of the incidents or a tunnel vision that the interrogator has in mind. This second one is the focus of this research paper.

As its name suggests, the term "interrogation" refers to the most common and frequent type of interaction, the question- answer sequence in institutional formal discourse. Atkinson (1982: 96- in Delin, 2000: 88) refers to the link between formal interactions and the questionanswer sequences. He says: "Formal interactions are frequently conducted through pairs of turns that are recognizable as questions and answers, with the professional(s) providing most of the questions and the interviewee or private individual providing most of the answers." Police interactions with possible suspects pass through three stages of investigation: interviewing, questioning and interrogating (Gehl, R. and Plecas, D. 2017).

\section{II. a. Interviewing:}

Interviewing is the first, easiest and lowest stage of interaction. In interviewing, the suspected person may be a witness of the crime, a passer- by or even a victim. Williamson (1993: 98) claims that the aim of "investigative interviewing is to obtain accurate and reliable information from suspects, witnesses or victims to discover the truth about matters under police investigation". As a result of investigations and discussions during the interview, this person will be let go or he will be promoted to become a suspect.

\section{II. b. Questioning:}

Questioning is the second stage of investigative interaction. It comes next to interviewing. It starts when the interviewer obtains a circumstantial evidence against the suspected person. In this case, the interviewer detains the suspect and provides him with "Section 10 Charter of Rights and Freedoms" that grants him the right to remain silent. The grant represents a real warning to the suspect to watch his words because they may be taken as evidence against him later in court.

\section{II. c. Interrogation:}

Interrogation is the third and most dangerous stage of police interaction. It is preceded by questioning and interviewing. It happens after serious evidence is obtained against the detained suspect. It always occurs in an institutional environment, mainly in the interrogation room. In it, the hands of the suspect become chained. As interrogation is highly 
important to the future life of the suspect, it is preserved by all means. Not only is it transcribed but also it is audio and video recorded. This helps keep all the minutest details of interaction during interrogation. In his attempt to obtain a confession from the suspect, the interrogator should not be aggressive or biased. Rather, he should be objective and tolerant. The suspect may be offered food or drink. Also he should be told to seek a lawyer to defend him. In case of not having a lawyer, he may be offered one for free. Perceiving the seriousness of the situation, the suspect attempts to exonerate himself by giving evasive answers to the questions he is asked. In fact, it is really a hard task to achieve a successful interrogation between the interrogator who seeks the truth and the suspect who deceives through evasion.

\section{Research Objectives:}

The research attempts to answer the following questions:

1. What are the discoursal strategies that police interrogators use to obtain confessions from their suspects?

2. What is evasion? And how is it used as a deceptive strategy?

3. How do suspected criminals manipulate language to evade and deceive police interrogators?

4. How do police interrogators react against their suspects' evasive answers? How do they manipulate questioning for the detection of evasion? In other words, what are the tactics used by the interrogators to prompt answers from their evasive suspects?

IV. The Transcript of the Interrogation of Anthony Sowell: The Data for Analysis

The research deals with the first part of the transcript of the interrogation of Anthony Sowell as its data for analysis. Anthony Sowell is an American real serial killer accused of killing at least eleven women over two years, from 2007 to 2009 . He used to lure his victims to his home by promising to offer them food, beer and dope. In his duplex, he kidnapped, assaulted and raped many others also. He used to rape and torture his victims several times and then to strangle them. He buried them in shallow graves in his basement and back yard. The importance of Anthony Sowell to this research lies in the fact that his real case represents a plea against the American police. He deceived the police by 
his decent appearance and friendly behavior in the neighborhood. The police did not believe the women who accused him of threatening their safety. They overlooked the allegations raised against him by the victims who were lucky to survive and escape from his hands. That is why the police were obliged to pay $1,300,000 \$$ as a compensation for the victims' families after his being convicted. Part of Anthony Sowell's evasive strategy was in the very selection of his victims. He was very careful to select women who were disreputable, homeless, lonely and dupeaddicted. Consequently, their presence was not reported or even noticed in most of the cases. Simply, they were "no body's women" (Miller, 2012).

And when people in the neighborhood complained about the terrible stinking smell in the air, the blame was always on the meat factory in the area. The smell got worse to the extent that the authorities in the city obliged the honors of the factory to change the whole line of drainage pipes in this area. Of course, it cost a lot. In fact, Anthony Sowell was a very lucky criminal. He could escape with his crimes and repeat them many times without being noticed. But things do not proceed like this all the time. They must come to an end. The last surviving victim, called Melvett Sockwell, went to the police and reported that he raped her several times for 12 hours, tied her hands behind her back, gagged her mouth and threatened her life. Fortunately, he felt very exhausted. He bluntly said to her: "You might as well say your prayers, because I'm going to kill you. (He was staring straight through her.) I'm going to beat you, and then I'm going to kill you. But I'm going to sleep first because I'm too tired to kill you right now. (He took a nap)" (In Miller, 2012). When the police officers went to his house to question him about Melvett's report, he was not there. Inspecting the place, they discovered the distorted corpses of his victims in the basement of his duplex. Therefore, they arrested him and started their interrogation of him.

\section{Theoretical Preliminaries:}

\section{V. a. Linguistic Deception:}

Linguistic deception is a way to avoid telling the truth. De Paulo (2003: 74) describes it as "a deliberate attempt to mislead others". This also goes with Arcuili, J. et al., 2010: 397). Atkinson (1996) proceeds further and regards deception as "displacement". He makes the link between 
deception and displacement which is known as a property of human language that gives the chance to language users to talk about many things that are absent in the immediate context like fairy tales, science fiction or things like these (Yule, 2007: 9). Deception is totally against the well-known proposition that all people have to tell the truth and nothing but the truth. But in real everyday life things never proceed likewise. Lying is around us everywhere in our daily communicative interactions. It is like a vicious circle where we all lie and are lied to. Children lie to their parents about their misbehavior; students lie to their teachers about the homework they did not do; patients lie to their doctors about their complaints to obtain more care; employers lie to their managers about the causes of their delayed arrival to work; politicians lie to their people about their programs; and etc. Some researchers claim that a person lies at least once or twice daily (De Paulo, et. al, 1996; Hample- in Robinson, 1996: 89). People lie for a variety of reasons that may reverse from being very simple to very serious. They lie to save one's face, to be affiliative or to avoid losing ground in a conversation. But concerning suspected criminals and their police interrogators, the situation becomes very hectic. In police-suspect interrogating discourse where the suspect is fully aware that if he tells the truth, as really as it is, his life will be at stake, he resorts to deception to exonerate himself. He deliberately misleads his interrogator by giving him evasive misleading information.

\section{V. b. Types of Deception:}

Deception is not an easy task to be performed. It can be hidden or apparent. Whaley (1982: 180) claims that deception operates through "dissimulation and simulation". Dissimulation is covert as it is about "hiding the real". But simulation is overt as it is based on "showing the false". Galasinski (2000: 22) talks about the same thing and classifies deceptive communication into deception by "omission and commission". He argues that deception by "omission" happens when the deceiver "withholds some information from the target". In this case, the deceiver is called a "passive" one because he does not mention the whole information. He withholds part of it through his silence. But he does not falsify the truth. Just, he hides a piece of it. On the other hand, deception by "commission" occurs when the deceiver distorts information "explicitly 
or implicitly". In this case, the deceiver is called an "active" one. The active deceiver offers information to his target in a way that serves his deceiving intentions. In other words, he pushes his target forward in the direction that fits his evasive purposes. Bouwmeester (2017: 139) makes the link between deception and the political and military life. He states that Russian warfare is mainly built upon "maskirovka and reflexive control". He classifies deception into the same aforementioned two types but he labels them differently as "maskirovka" and "reflexive control". Maskirovka works on the psychological dimension of the target by offering him false information. It tends to destroy the psychology of the opponent indirectly and covertly. Turning to reflexive control, we find that it offers another type of deceit to the opponents. Its deceit is overt. In this case, only a little piece of correct information is offered inside a jungle of wrong information. Thus, the opponent's response becomes compatible with the results that the deceiver has planned for in advance. In reflexive control, the opponent ends with a heap of broken images where he cannot identify the true information from the false one.

\section{V. c. Evasion as Deceptive Discourse:}

Discourse is like a game. And people are the outcome of their "performance" of this game in actual communicative interactions. "Performance", or mainly "performativity", goes back to Austin's speech act theory (1962). He argues that whenever we speak, we do not produce words in vain. Rather, we are performing actual acts of stating, promising, threatening, etc. Gee (2005: 19) talks about "performance" in discourse and calls it a "dance". He draws a triangular relationship between discourse, performance and dance. He says: "Like a dance, the performance here and now is never exactly the same. It all comes down to what the 'masters of the dance' will allow to be recognized or will be forced to recognize as a possible instantiation of the dance."

The "masters of the dance" are the people who participate in this discourse. Their manner of performance reflects the macro level descriptions of discourse. Dealing with discourse as a game or performance makes us able to pinpoint instances of cooperation, noncooperation, evasion, deception, etc. In such cases, the deceiver manipulates discourse in a way that makes him in full control of the information delivered to the target. He can misrepresent, distort or even 
hide it. Bell (2003: 244) defines deception as "the conscious planned intrusion of an illusion seeking to alter a target's perception of reality, replacing objective reality with perceived reality".

Galasinski (2000: xi) makes the link between evasion and the questionanswer strategy of interaction. He attributes evasiveness mainly to answers of the questions. He argues that in press interviews, the deceiving person assumes being cooperative whereas in fact he is far from being so. Rothstein and Whaley (2013: 19-20) point out that "nothing is ever 'just' hidden, something is always shown instead, even if only implicitly". The evasive game is based on two players: a deceiver and a target. A deceiver is the one who deliberately conceals or presents irrelevant information while answering the questions offered to him by the interviewer or the target. Evasion is basically a process, followed by the deceiver, to falsify perception from the part of the target to become misperception. It is something like a competition where one party attempts an evasive tactic and the other party attempts to contraindicate it. Consider the following interview between a police officer (P.) and a Suspect (S.). The suspect is a serial killer convicted of killing his women patients. However, he denies all the charges.

“P. The entry for (.) Mrs Grundy's visit on the $9^{\text {th }}$ of June, (.) will you tell me why (.) there was no reference there (.) to you taking any blood from her.

$(-)$

S. $\rightarrow$ normally (all) the blood results come back two days later.

P. no but (can you tell me) why there's no (.) mention on that date.

S. I cannot give you an explanation." (In Haworth, 2006: 746)

The suspect's answer assumes cooperation. But in fact he does not cooperate. Instead of answering the police's question on the cause of not taking any blood from the victim, Mrs. Grundy, the doctor's response is about the system of the hospital. Perceiving the suspect's evasive answer, the police officer repeats his question again to prompt an answer from him. S is very clever in using evasion. S's first answer belongs to covert evasion whereas his second one belongs to overt evasion.

\section{V. d. Types of Evasion:}

\section{V. d. 1. Covert Evasion:}


Covert evasion deals with the semantic relevance of the interviewee's answers to the questions asked to him by the interviewer. It is mainly concerned with the informative part of the message. Galasinski ( 2000: 63-5) claims that the evasive interviewee can cover his evasion through three strategies: 1) changing the textual context of the question; 2) changing the focus of the question; and 3) changing the focus and the textual context of the question. Clayman and Heritage (2002- in Griffenhagen, 2009: 15-16) follow Galasinski's (2000) same line of thought. Consider the following example of evasion. It deals with the first strategy of covert evasion. In it, the evasive speaker changes the textual context of the interviewer's question.

"A: What will the KPN [Confederation of Independent Poland] exactly do, if it takes over power tomorrow?

B: If we take power, first of all, people will have some prospect that within weeks- weeks, not years- the economic situation will start to improve." (Galasinski, 2000: 62)

Here, instead of offering an answer related to the action that the KPN will do, B says again some part of the question asked to him in the answer. Thus, he gives the impression that he is offering a direct answer to the question whereas he is just reinterpreting it no more. Clayman (1993: 163) notes that the interviewee's reformulations or paraphrases are not accurate repetitions of all the words uttered in the question. Rather, they are masquerades of them.

The second strategy of covert evasion occurs when the evasive speaker changes the focus of the question asked to him. The interviewee maintains the same context and makes changes related to the main topic of the argument. So, instead of speaking about the topic, he speaks topically. Notice the following example:

“UK PBS Newshour: 21 Jan 1998: Monica Lewinsky

IR: Jim Lehrer IE: Bill Clinton

IR: You had no sexual relationship with this [young wo[man.]

IE: [ml [Th-]

IE: $\rightarrow$ There is not a sexual relationship. That is accurate."

(Clayman and Heritage, in Greiffenhagen, 2009:16)

Here, IE changes the focus of the question by altering the time frame of the action. In so doing, he changes the tense of the verb. Consequently, 
he evades the question about the past actions and offers an answer that deals with something else. IE's answer is about the present time rather than the past one. Instead of confessing his past relationship with Monica, Clinton says that there is not a sexual relationship in the time being.

The third strategy of covert evasion happens by altering the focus and the textual context of the question. The interviewee might afford an answer that is incoherent to the question. Or, he can select only one part of the question to be answered and overlooks the rest of it. Look at the following example:

“UK BBC Newsnight. 13 May 1993: Michael Howard

IR: Jeremy Pexman IE: Michael Howard

IR: Did you threaten to overrule him.

IE: I did not overrule Der [ek (Lewis).

IR: [Did you threaten to overrule him" (Ibid)

Evasion is achieved here by changing lexicon used in the question. Instead of answering about a specific action, 'threatening', the evasive speaker's answers are about 'overruling'. Consequently, IR repeated his question again with the same lexicon to compel IE to answer properly.

\section{V.d. 2. Overt Evasion:}

Evasion can be overt as well as covert. Ostensibly, covert evasion is a prerequisite for deception. No one can deceive others without concealing his intentions. But overt evasion is not necessarily deceptive. This means that the evasive speaker can just declare his non-cooperation by "optingout" as Grice calls it. So, utterances like "no-comment", "nothing further to add" (Galasinski, 2000: 67) or any similar ones are all overt ways of evasive communication. Following the same line of thought, Carnaghan (1996- in Scoboria, 2013: 73) speaks about "nonresponse items". He identifies utterances like 'don't know', 'refusal', 'not applicable' and 'no answer' as codes for them. He maintains that 'an 'I don't know' response can cover a variety of meanings: from utter lack of interest, over a carefully considered but inclusive debate between different response categories, to a refusal to reveal sensitive or controversial opinion."

\section{V.e. Questioning and the Detection of Evasion:}

Questioning and evasion are two related concepts. Researchers cannot study one and leave the other. Evasive answers are always the result of 
imposing questions that compel their receivers to offer specific answers. Harris (1984: 21) argues that in legal settings, questions perform two functions: information and accusation. She points out that "requests for confirmation can apply either to questions relating to information or to accusations". In police- suspect interrogations, the relationship between the interrogator and the suspect is a direct one. The more the answers of the suspect are evasive, the more the questions of his interrogator become indirect and subtle. Leo (1994: 97) shares the same view and says: "Today's interrogators are more instrumentally rational in their goals, employing subtle and sophisticated questioning techniques in order to efficiently and legally compel admissions and confessions."

Researchers have remarked that certain questioning patterns are concurrent to specific discoursal actions. Heritage and Sorjonen (1994: 129) worked on contingent questions in medical discourse between health care visitors and new mothers. Clayman and Heritage (2002) and Raymond (2003) worked on questions with built in presuppositions in media discourse. Ehrlich and Sidnell (2006: 658) called them "presupposition triggers". Koshik (2010- in Fred and Ehrlich, eds., 2010: 12; and Sidnell, 2010- in ibid: 23) worked on "reversed polarity" in classrooms and legal settings. Atkinson and Drew (1979), Drew and Heritage (1992), Drew (2003) and Holt and Johnson (2010) worked on "next questions", "formulations", "repeating questions" or "echo questions" in news discourse and police interviews. They all spoke about the same thing but they labeled it differently.

\section{V. e. 1. Contingent Questions:}

Heritage and Sorjonen (1994: 11) classify questions according to the functions they perform in communication. They argue that questions are either "contingent" or "routine". Contingent questions are also called "follow-up" questions because they bring the answerer back to the direction that the interviewer has in mind. On the other hand, routine questions are also called "agenda-based" questions because in them the answerer bends smoothly to the rules of the game of discourse. He follows typically the agenda that is prepared to him in advance. According to them (ibid), contingent questions are the ones that show that a problem in communication exists. They are not prefaced with the coordinating "and". On the other hand, routine questions are no problem 
ones that show that communication proceeds smoothly. They are prefaced with "and". This concurs with Holt and Johnson (2010- in Coulthard and Johnson, eds., 2010: 25). They claim that "so- prefacing questions" in particular are highly significant for the establishment of evidential discourse in legal texts. But sometimes, and- prefacing questions are used to show that something wrong is occurring. They are used to shed light on this interactional problem. Drew (1992: 510) claims that "and- prefacing questions" can be used to fulfill the function of contingent questions. They refer to "puzzling or inconsistent" events. Consider the following exchanges between a cross examining lawyer (D) and a witness $(\mathrm{W})$ :

"1 D: Now (.) subsequent to this uh (0.6) uh you say you received uh

2 (0.8) a number of phone calls?

$3 \quad(0.7)$

$4 \mathrm{~W}$ : Ye:s.

5 (0.4)

$6 \mathrm{D}$ : From the defendant?

7 (1.2)

$8 \mathrm{~W}$ : Ye:s

$9 \quad(0.8)$

$10 \mathrm{D}: \rightarrow$ And isn't it a fa:ct uh (.) Miss ((Name)) that you have an

11 Unlisted telephone number?

12 (0.3)

13 W: Ye:s.

$14 \quad(1.2)$

$15 \mathrm{D}: \rightarrow$ An' you ga::ve the defendant your telephone number didn' 16 You?

$17 \mathrm{~W}:$ No: I didn't.

$18 \quad(0.3)$

$19 \mathrm{D}:$ You didn't give it to [him

20W: [No:."

In this example, the attorney perceives the inconsistency in the testimony of the witness's answers. So, he resorts to a series of successive andprefaced questions to solve perplexities in his sayings. And- and soprefacing questions are considered markers that identify unexpected or 
problematic answers in the interrogation. They help the interrogator to bring back his suspect to the main agenda and to avoid evasive responses.

\section{V. e. 2. Presupposition Triggers:}

There are some questions that trigger presupposition. They are a type of cunning questions that embody further implicit meaning that is included indirectly in them. The danger of these questions lies in the fact that if the answerer is not alert enough to them, he will find himself offering confessions about things he does not want to be involved in. Yule (2007: 117) calls them questions with built-in presuppositions. Consider this question which is asked by an interrogator to his defendant: "Okay, Mr. Smith, how fast were you going when you ran the red light?" (ibid). Here, by answering the 'how fast part?' the defendant indirectly confesses that he ran the red light.

\section{V. e. 3. Reversed Polarity:}

A reversed polarity question is a special type of nondirective interrogations. It is a polar question as it belongs to the 'yes/ no' type. And it is reversed because although it is affirmative in form, it carries negative connotations. Consider this question which is given by a teacher to his student. The teacher is not satisfied by the student's work. He asks his student: "Is that what your essay about?" The question communicates a negative assertion that 'that is not what your essay is about' (Ehrlich and Fred, 2010: 12).

\section{V. e. 4. Next Questions:}

In courts, cross examining interrogators manipulate their questions in a way that complies with their knowledge about the succession of events. They endeavor all the time to push their perpetrators to give them descriptions of the events in a way that is compatible to what their victims have said about them (Atkinson and Drew, 1979: 180). In so doing, they use 'next questions', 'reformulations', 'repeating questions' or 'echo questions'. In fact they are all used interchangeably to refer to the same thing, to push their interviewees towards the intended target. As they reformulate or repeat the previous utterance of the interviewee, they represent the next upcoming question to be asked (Holt and Johnson, 2006- in Holt and Johnson, 2010: 30). Consider the following extract between a suspect $(S)$ and a police officer $(P)$.

"S: [Yeh. 
$\mathrm{P}: \rightarrow$ Right. Okay. So you've admitted the criminal damage basically with eggs.

$P$ : And other fo:od.

S: Y(h) e (h) a (h)h." (Stokoe and Edwards, 2008: 104)

Here, the police officer succeeds through the use of next question to reformulate a confession about the suspect's acts of throwing eggs upon his neighbor.

\section{Theoretical Framework:}

This research studies evasion in police-suspect interrogating discourse. It analyzes the transcript of the interrogation of Anthony Sowell from a discourse analytic point of view. The framework of this research is twofold. On one hand, it works on the level of evasion, covert and overt, from the part of the suspect. And on the other hand, it inspects the detection of evasion by the police interrogators. The research applies a theoretical framework that studies covert evasion from the following three perspectives: 1 ) changing the textual context of the question; 2) changing the focus of the question; and 3) changing the focus and the textual context of the question (Galasinki, 2000). And concerning covert evasion, the research focuses on 'opting out'. As for the detection of evasion, the theoretical framework of this research spots light on the interviewers' reactions towards this evasion. It uses 'contingent questions', 'presupposition triggers' and 'next questions' as frameworks for the detection of evasion. Two types of contingent questions are discussed: 'and- and so- prefacing questions. For the sake of brevity, the research will handle the questions and their responses at the same time because they are interrelated together.

\section{Analysis of Data:}

VII. a. Covert Evasion:

\section{VII. a. 1. Changing the Textual Context of the Question:}

Anthony Sowell is a professional serial killer. He could pass unimpeded by his crimes for two whole years. Hence, his interrogation is not an easy task. One of the strategies that he used during his interrogation is to change the textual context of the question. Whenever the interrogators 
ask him a question, he achieves this kind of covert evasion by repeating a part of the question, paraphrasing it or reformulating it. Sometimes, he changes the subject pronoun he is asked about. Thus he gives the impression that he is answering the questions. But his answers are irrelevant. Consider the following extract between him and Detective Durst about his mother's address:

"Det. Durst: Where does Claudia live?

Mr. Sowell: $\rightarrow$ She lives with my sister.

Det. Durst: Which is where?

Mr. Sowell: Right there on Abell, $130^{\text {th }}$ and Abell (.)I don't know the address for her(.) ((Inaudible)) know it." (Transcript, 2009: 15)

In this extract, Anthony widens the context of the question. Anthony's answer is irrelevant to the question asked to him by detective Durst. The question is about 'where'. But the answer is about 'with whom'. Perceiving this evasion, Durst repeats his question again. This compels Sowell to offer another answer appropriate to the question.

This transcript is replete with many instances of covert evasion through the changing of the textual context of the question. Check this extract. It is between Sowell and Detective Baumiller about the dead women who were found in his house.

"Det. Baumiller: Tony, what was it about the folks we found in your house that pissed you off? They are different than the folks you normally help, right?

Mr. Sowell: $\rightarrow$ I help anybody (.)

Det. Baumiller: But this isn't the neighbor that you're helping with the sink (.) Maybe you helped these people because they wanted to get a buzz or something (.) I don't know, you tell me. You got to tell us, Tony, what happened in that house?

Mr. Sowell: I don't - I don't remember like that (.)" (ibid: 62) In this example, Sowell generalizes the context of speech. Instead of responding about the women, he speaks about himself by using the pronoun ' 1 '. He offers a picture about himself that depicts him as a helpful personality whose help is not to specific people but to 'anyone' in the whole wide world. Ostensibly, he gives a coherent answer that deals with 'help'. But underneath, his answer does not relate to the question. It is 
about something else. Still, he does not tell us about 'the women' or what happened to them. That is why Detective Baumiller commented on his answer by using the directive 'You got to tell us' to elicit the required information from him.

\section{VII. a. 2. Changing the focus of the question:}

The second strategy of covert evasion is achieved through the changing of the focus of the question. Anthony Sowell manipulates this device several times to evade the questions of his interrogators. Consider the following example. It is between Sowell and Sergeant Rini about the relationship between him and one of his victims called LaLa.

"Sergt. Rini: Why should she come to us with a different version?

Mr. Sowell: I don't know, I don't know what her ((inaudible)) -

Sergt. Rini: You are buying her scoobies?

Mr Sowell: $\rightarrow$ I WON'Tbuy her no more, know(.)

Sergt. Rini: You're giving her straight sex?

Mr. Sowell: $\rightarrow$ I WON'T buy her no more (.) I WON'T BUY HER NO MORE(.)She ate and everything." (Ibid: 39)

In this exchange, Sowell changes the focus of the argument by changing the tense of the utterance. He changes it from the affirmative present progressive 'are buying' to the negative future one 'won't'. Then he follows it by the past tense 'ate'. Therefore, he shows that this relationship has ended. It does not exist anymore and will never exist again. He asserts this by repeating the same utterance thrice.

\section{VII. a. 3. Changing the Focus and the Textual Context of the question:}

In his attempt to exonerate himself, Sowell again uses covert evasion by making a combination between the first and the second strategies mentioned before. Thus, he exerts endless efforts to evade any question that might put him at risk. Consider the following extract.

"Det. Smith: To me, I may be wrong, so you can correct me if I'm wrong,

It appears that you came in and rushed out real quick (.)

Mr. Sowell: $\rightarrow$ I came in - I didn't rush out, I just left (.)

Det. Smith: Okay.

Mr. Sowell: As a matter of fact, I usually keep my ID (.) I had just forgot.

I remember - I know I left the cigarettes but when I went to 
Look for my ID, ((inaudible)) I left it in the house." (ibid: 108) Here, Sowell is very cautious about his words. He knows very well that whatever he will say will be taken against him. Sowell bluntly says to his interrogator: "I know the game. I'm just trying to do the best I can" (ibid: 96). Of course, he does his 'best' to hide the truth and not to declare it. Really, it is a game of witness. In this exchange, Sowell asserts the part that shows that he 'came in' but denies the other part that shows that he was in a hurry. He says 'I didn't rush out, I just left'.

Another striking example of Sowell's ability to change the focus and the textual context of the question is the following one. Here, he changes both the context and the focal point of the argument. Consider it:

"Srgt. Rini: When you get to the house, where do you guys end up?

Mr. Sowell: We just drinking, she smoking, we drinking and talking, we got something to eat, we had sex, she stayed there all day(.)

this is early in the morning, 6:00 in the morning, she didn't

leave until five that evening, five, six that evening (.)" (ibid: 29) Instead of giving an answer related to 'where' part of the question that requires reference to a specific place, Sowell speaks of the activities that they performed together. He focuses only on the 'when' part and neglects the other part of the question. His aim is to prove that she safely left his house.

The following table offers a summary of the three strategies of covert evasion that Sowell manipulates during his interrogation.

Table (1)

\begin{tabular}{|c|c|c|}
\hline $\begin{array}{l}\text { Strategies of covert } \\
\text { evasion }\end{array}$ & Page number & Frequency \\
\hline $\begin{array}{l}\text { 1.Changing the } \\
\text { textual context of } \\
\text { the question }\end{array}$ & $\begin{array}{c}15,26,28,48,49,50,58,62,64,76,77,78,80 \\
81,83,85,87,90,99,103\end{array}$ & 20 \\
\hline $\begin{array}{l}\text { 2. Changing the } \\
\text { focus of the } \\
\text { question }\end{array}$ & $\begin{array}{c}6,17,18,25,27,28,30,31,36,39,45,47,60,74 \\
75,77,81,82,84,86,89,99,109,110,113\end{array}$ & 25 \\
\hline $\begin{array}{l}\text { 3. Changing the } \\
\text { focus and the } \\
\text { textual context of } \\
\text { the question }\end{array}$ & $\begin{array}{c}13,29,32,49,52,62,65,66,76,78,81,83,86 \\
88,89,91,108,114\end{array}$ & 18 \\
\hline Total & & 63 \\
\hline
\end{tabular}

VII. b. Overt Evasion: Opting out 
Anthony Sowell is a suspect who manipulates overt as well as covert evasion during his interrogation. Being an experienced criminal who spent around fifteen years in jail for a rape conviction, he is fully aware of the rules of the interrogating game. He knows that the effect of silence is not recommended in interrogations. So, whenever he is obliged to afford an answer about a specific question that makes him convicted, he resorts to overt evasion immediately. In so doing, he opts out and produces unresponsive items devoid from relevant information. Sometimes, he produces utterances that indicate his clear refusal to answer the questions asked to him by his interrogators. Overt evasion serves the double function of giving the sense that he is cooperative. And at the same time, the information that he affords through it is a big nothing. So, whenever he gets cornered, he uses utterances like 'I don't know', 'I don't remember' and 'I'm not going to tell you'. Check the following example:

"Det. Baumiller: Tone, how did you help the people we found in your house? (.) What did you do for them?

Mr. Sowell: There's so much I do (.) Just--I feed--

Det. Baumiller: Let's talk about the girl in the basement under the dirt. How did you help her?

Mr. Sowell: $\rightarrow$ I don't know.

Det. Baumiller: You didn't help her?

Mr. Sowell: $\rightarrow$ I don't know(.) I don't --

Srgt. Rini: Do you know her street name?

Mr. Sowell: $\rightarrow$ I don't - I can't remember(.)

Det. Baumiller: Was she like LaLa, did you buy her a rock?

Mr. Sowell: $\rightarrow$ I can't remember(.) I'll think about it(.)

Det. Baumiller: I know you did something to help her(.)

Mr. Sowell: $\rightarrow$ I ca::n't remember(.)

Det. Durst: Can you remember how you helped any of them?

Mr. Sowell: $\rightarrow$ I don't know(.)

Most of the time (.) I just buy people food, cook for them.

Clothes dope sometimes(.) Oh, like the girl upstairs ((inaudible)) she always needed to borrow a few bucks, a few bucks, a few bucks(.) Just I give her ((inaudible))." (Ibid: 74-75) 
In this extract, Sowell is interrogated by three officers. Their main objective is to elicit information from him about the strangled victims in his house. Sowell attempted covert evasion in his first answer. He changed the focus of the topic of the question by shifting the tense from past to present and the subject pronouns. The questions are about 'how and what did you...?' but the answer is about 'there is so much I do'. Instead of talking about what he did to these women, he generalizes the topic of conversation and turns it into a discussion about his beneficent deeds. Perceiving this evasion, Detective Baumiller reformulates the question and asks him again about a specific girl in particular. In this case, Sowell changed his strategy of covert evasion and manipulated the overt one. He kept producing the utterances: 'I don't know, I'm thinking and I can't remember'.

The following table presents the instances of overt evasion through opting out in Anthony Sowell transcript of interrogation.

Table (2)

\begin{tabular}{|c|c|c|}
\hline Opting out & Page number & Frequency \\
\hline I don't know & $\begin{array}{c}19,26,39,45,52,64,74,75,77,78,79, \\
80,86,88,89,92,121,122,126,127\end{array}$ & 20 \\
\hline I don't remember & $62,78,79,89$ & 3 \\
\hline I'm not going to tell you & 54 & 1 \\
\hline I don't want to talk about her & 112,113 & 2 \\
\hline Total number & & 26 \\
\hline
\end{tabular}

\section{VII.c. The detection of evasion:}

VII.c. 1. Contingent questions:

On their attempt to detect Sowell's evasive answers during his interrogation, the detectives use contingent questions in the form of 'andand so- prefacing questions'. Once these questions are used, we get to know that a problem in communication is taking place. The following extract is between Sowell and Detective Durst about one of the kinky women he rapped. Sowell states that she asked him to buy her Scooby. He denies that he attempted to strangle her by using an ironing cord. Rather, he claims that she asked to whip him by it. Check these utterances. They offer an example of 'and-prefacing questions'.

"Mr. Sowell: I'm at Chillie's when I meet her(.)

Det. Durst: So you meet her at Chillie's? 
Mr. Sowell: I'm getting ready to go right in the door(.) She's at somebody's car(.) She sees me so she come over to me and that's when we get to talking(. )I'm going over here to buy this beer and then I'm going home(.) When I came out she was right there waiting on me(.)

Det. Durst: $\rightarrow$ And then she sa::ys buy me a scooby?

Mr. Sowell: We went right there on her way because she knew the people going down $116^{\text {th }}$ so she called somebody and she got it right there(.)

Det. Durst: $\rightarrow$ And then all of a sudden(.) she says I want to bang you?

Mr. Sowell: She said that before(.) She said that at Chillie's when she first seen me(.) She said where are you going, is you going home, I said yeah, I just want to get this beer and stuff(.) She said well why won't you buy me a scooby, we will go back to your place because I want to - whatever she said, I'm not sure about the exact words but that's what she said(.) That ironing cord thing didn't come then(.) It was like on the way." (Ibid: 28-29)

Here, the 'and- prefacing questions' occur at points where Detective Durst does not believe Sowell. Detective Durst uses them to refer to puzzling and inconsistent events. In the first instance, Durst uses it to reflect his astonishment about the succession of events in Sowell's story. In the second instance, Durst asserts this sense of surprise by repeating the adverbial transition 'then' again and following it by 'all of a sudden'. This second 'and- prefacing question shows that Durst is totally unconvinced by the suspect's statements. However, Sowell uses another evasive response. He changes the focus of the topic by changing the tense from 'present' to 'past'. His answer shifts the tense from the present 'say' to the past 'said'. Also he intensifies his answer by using the adverb 'before' to indicate that this was not her first time.

The following extract presents an example of "so- prefacing questions". Check these utterances:

"Det. Baumiller: So you been to your sister's lately?

Mr. Sowell: I'm always at my sister(.)

Det. Baumiller: Were you there like, I don't know, yesterday? 
Mr. Sowell: No(.)

Det. Baumiller: $\rightarrow$ So where you been the last couple of days?

Mr. Sowell: I was at - I stayed in the house they say they seen me coming out of(.)" (ibid: 47)

In this extract, Detective Baumiller notices Sowell's covert evasion in the first answer. Sowell changes the focus of the topic of Baumiller's question by changing the tense of the verb from the past "been" to the present "am". Also, Sowell asserts his answer by the use of the frequency adverb "always". Then Baumiller uses a closed question of the yes/ no type to oblige Sowell to give a strict answer. Baumiller uses the "so- prefacing question" to push Sowell forward in the right non- evasive direction. Thus, Baumiller gets the answer that he has in mind from Sowell.

\section{VII. c. 2. Presupposition triggers:}

Presupposition questions are those tricky questions with built in presuppositions. If the suspect is not alert to them, he might find himself in a big dilemma because of his response upon them. They are highly dangerous because they carry convicting claims within them. Applying this to Sowell's case, the detectives used them more than one time with him. Consider the following example:

"Det. Baumiller: How come you didn't go home?

Mr. Sowell: To my sister's?

Det. Baumiller: No, to your house(.)

Mr. Sowell: Because I knew you all was looking for me(.)

Det. Baumiller: $\rightarrow$ Did you see all those trucks out there?

Mr. Sowell: I didn't go past there(.)" (Ibid: 48)

Here Sowell's negative answer 'I didn't go past there' asserts the fact that he was not at the house. Baumiller's question 'did you see all those trucks out there' carries the presupposition that Sowell was there. So if Sowell affirms this claim by saying 'yes', this immediately entails that he was there in the area by that time.

VII. c. 3. Next questions:

Next questions occur many times in the cross interrogation of Anthony Sowell. They are used by his interrogators to elicit information which is compatible to their vision about the succession of events. Using next questions, the interrogators can detect evasive answers offered to them by the suspects. Consider the following extract. 
"Det. Durst: What about like the house, what would the house look like because when you did some - you did some damage(.)

Mr. Sowell: It would be regular(.)

Det. Durst: $\rightarrow$ Like a:Il cleaned up and everything? And then what I mean what would happen like - so everything would be cleaned up and you would think nothing of it?

Mr. Sowell: I just cold(.)

Det. Durst: And what did you start to think when-

Mr. Sowell: Get cleaned up and go(.)

Det. Durst: Would you throw stuff away?

Mr. Sowell: No.

Det. Durst: $\rightarrow$ You would keep everything?

Mr. Sowell: No. What you mean I throw everything away? I don't understand(.)

Det. Durst: Well like the people that are dead, there was probably Blood on the [floor(.)

Mr. Sowell: NOT when I came to(.)" (ibid: 87-88)

In this extract, Durst attempts to push Sowell forward to tell him about the damages that result from the process of killing the women in the house. He wants to get information about the after mass and the cleaning up process. Durst' first 'next question' is a reformulation of Sowell's previous answer, 'it would be regular'. However, Sowell's answer to this question is evasive. Sowell changes the textual content of the question. Instead of giving an answer about 'think', he answers about 'feeling cold'. As a result to Sowell's covert evasion, Durst's second next question, 'you would keep everything?', is a reformulation of his previous question, 'would you throw stuff away?' And again, Sowell uses covert evasion by repeating part of Durst's question. In so doing, he changes the textual context of his interrogator's question. Thus, we notice that both Sowell and his interrogators are participating in a discoursal game of evasion and its detection.

The following table is about the detection of evasion in the interrogation of Anthony Sowell. Evasion is detected through contingent questions, presupposition triggers and next questions.

(Table 3)

\begin{tabular}{|c|c|c|}
\hline Codes for the detection of & Page number & Frequency \\
\hline
\end{tabular}




\begin{tabular}{|c|c|c|}
\hline \hline evasion & & \\
\hline 1.Contingent Questions: & $27,28,42,70,82,83,86,87,91$ & \\
1.a.And- prefacing questions & $6,27,28,47,50,55,65,77,79$, & 9 \\
1.b. So- prefacing questions & $82,83,88,89,90,108$ & 15 \\
\hline 2. Presupposition triggers & $13,48,55,88,89$ & 5 \\
\hline 3. Next questions & $8,13,15,42,43,51,81,87,88$, & 11 \\
\hline Total & 90,91 & 40 \\
\hline
\end{tabular}

\section{Conclusion:}

This research paper has studied evasion in police- suspect interrogating discourse. It has offered a discourse analytic study of the transcript of the interrogation of Anthony Sowell. It showed that police interactions with suspects undergo three stages: interviewing, questioning and interrogation. As interrogation is the most serious one of them, it became the focus of work in this paper. Interrogation is always conducted through questions and answers. Interrogators ask questions and suspects answer them. But in cross interrogations, exactly like in Sowell's case, things don't proceed simply like that. Anthony Sowell, the Cleveland strangler in Ohayo City, tries to plead innocent. In so doing, he attempted most of the time to give evasive answers to exonerate himself. He really made his interrogators tired. Detective Baumiller said to him: "What we're looking for is to be honest with us some more" (ibid: 49). Also, Detective Smith said to him: "Obviously you know we have been there (meaning in the house). That's not an issue. So we don't have to argue and go around and around about that, you know" (ibid: 117).

Sowell manipulated discourse in a way that served his evasive purposes. In so doing, he used two types of evasion: covert and overt. Analysis of data showed that covert evasion is more common than overt one. Covert evasion occurs through three strategies: changing the textual context of the question, changing the focus of the question and changing the focus and the textual context of the question (Galasinski, 2000). The three strategies are all based on one thing, mainly change. The interrogator is asking about a specific thing and the interlocutor is answering another thing. On the other hand, overt evasion is done through opting out or giving nonresponsive items that are semantically irrelevant. The paper showed that evasion with its two types is deceiving because on the surface, the suspect seems cooperative, but underneath, 
he is not. Turning to the interrogators, they use language to detect evasion. They do so mainly through: contingent questions, presupposition triggers and next questions. They used them to identify problematic points in interaction with Sowell. The paper showed that the total number of Sowell's evasive answers is larger than the total number of the codes used by his interrogators to detect his evasion and to bring him back to the main version of events they have in mind. Thus, the research suggests that more work is required from the part of police officers to be able to maintain the equilibrium between getting information and not exercising coercion over the detained suspects. 


\section{References}

1. Atkinson, J. 1996. 'A nation is not. Law Bull'. In Pammer, J. and Killian, J., eds. A Handbook of Conflict Management. CRC Press.

2. Atkinson, J. 1982. 'Understanding formality: the categorization and production of "formal" interaction'. In British Journal of Sociology, 33, 86- 117.

3. Atkinson, J. and Drew, P. 1979. Order in Court: The Organization of Verbal Interaction in Judicial Settings. London: Macmillan.

4. Arciuli, J. et al. 2010. "Um, I can tell you're lying": linguistic markers of deception versus truth- telling in speech.' In Applied Linguistics, 31, 397- 411.

5. Austin, J. 1962. How to Do Things with Words. Oxford : Clarendon.

6. Bell, B. 2003. 'Toward a theory of deception'. In International Journal of Intelligence and Counter Intelligence, 16, 244-279. Taylor and Francis.

7. Bishilany, B., reporter. 2010.Transcript of the Interrogation of Anthony Sowell. Ohio: Cuyahoga County. http:// serialkillersinf.com

8. Bouwmeester, H. 2017. 'Lo and behold: let the truth be told- Russian deception warfare in Crimea and Ukraine and the return of "Maskirovka" and "Reflexive Control Theory"'. In Whaley and Rothstein, eds. 2017. Netherlands Annual Review of Military Studies 2017: Winning without Killing. Springer.

9. Carnaghan, E. 2009. 'Alienation, apathy, or ambivalence? "Don't knows" and democracy in Russia'. In Slavic Review, 55 (2), 325-363.

10. Clayman, S. and Heritage, J. 2012. The News Interview: Journalists and Public Figures on the Air. Cambridge: Cambridge University Press. 
11. Clayman, S. 1993. 'Reformulating the question: a device for answering /not answering questions in news interviews and press conferences'. In Text, 13 (2), 159, 188.

12. Delin, J. 2000. The Language of Everyday Life. Sage Knowledge.

13. De Paulo, B., et al. 2003. 'Cues to deception'. In Psychological Bulletin, 129 (1), 74-118.

14. De Paulo, B. et al. 1996. 'Lying in everyday life'. In Journal of Personality and Social Psychology, 70, 979- 995.

15. Drew, P. 2003. 'Comparative analysis of talk- in- interaction in different institutional setting: a sketch'. In Glenn, P. et al., eds. Studies on Language in Social Interaction. Mahwah, NJ: Lawrence Erlbaum Associates.

16. Drew, P. and Heritage, J., eds. 1992. Talk at Work: Interaction in Institutional Settings. Cambridge: Cambridge University Press.

17. Drew, P. 1992. 'Contested evidence in a courtroom crossexamination: the case of a trial for rape'. In Drew, P. and Heritage, J., eds. Talk at Work: Social Interaction in Institutional Setting. Cambridge: Cambridge University Press.

18. Fowler, R., et al. 1979. Language and Control. London: Routledge.

19. Freed, A. and Ehrlich, S., eds. 2010. "Why Do You Ask?" The Function of Questions in Institutional Discourse. Oxford University Press.

20. Galasinski, D. 2000. The Language of Deception: A Discourse Analytic Study. London: Sage Publications, Inc.

21. Gee, J. 2005. An Introduction to Discourse Analysis: Theory and Method. London: Routledge.

22. Gehl, R. and Plecas, D. 2017. Introduction to Criminal Investigation: Processes, Practices and Thinking.

23. Gibbons, J. 2003. Forensic Linguistics: An Introduction to Language in the Justice System. Oxford: Blackwell.

24. Goffman, E. 1981. Forms of Talk. Philadelphia: University of Pennsylvania Press.

25. Greatbatch, D. 1988. 'A turn-taking system for British News interviews'. In Language in Society,17 (3), 401-30. 
26. Greatbatch, D. 1986. 'Aspects of topical organization in news interviews: the use of agenda shifting procedures by interviewees'. In Media, Culture and Society, 8 (4), 441- 44.

27. Greiffenhagen, C. 2009. 'News interviews: Clayman and Heritage's "The News Inteview"' In Devine, F. and Heath, S. eds. Doing Social Science: Evidence and Methods in Empirical research. Basingstoke: Palgrave Macmillan.

28. Hample, D. 1996. 'A theoretical and empirical effort to describe message production'. Paper presented at the annual meeting at the International Communication Association. Chicago.

29. Haworth, K. 2006. 'The dynamics of power and resistance in police interview discourse'. In Discourse and Society. 2006. 17 (6), 739- 759. London: Sage Publications.

30. Heritage, J. and Sorjonen, M. 1994. 'Constituting and maintaining activities across sequences: and- prefacing as a feature of question design'. In Language in Society, 23, 1- 29.Cmbridge University Press.

31. Holt, E. and Johnson, A. 2010. 'Legal talk. Socio- pragmatic aspects of legal talk: police interviews and trial discourse'. In Coulthard, M. and Johnson, A., eds. The Routledge Handbook of Forensic Linguistics. Routledge.

32. Koshik, I. 2010. 'Questions that convey information in teacherstudent conferences'. In Freed, A. and Ehrlich, S., eds. 2010. "Why Do You Ask?" The Function of Questions in Institutional Discourse. Oxford University Press.

33. Leo, R. 1994. 'Police interrogation and social control'. In Social and Legal Studies,( 3), 39- 120.

34. Mishler, E. 1984. The Discourse of Medicine: Dialectics of Medical Interviews. Norwood: NJ Ablex.

35. Miller, S. 2012. Nobody's Women: The Crimes and Victims of Anthony Sowell, the Cleveland Serial Killer. New York: Berkley Books.

36. Raymond, G. 2003. 'Grammar and social organization: Yes/No- type interrogatives and the structure of responding'. In American Sociological Review, 68, 939-966.

37. Robinson, W. 1996. Deceit, Delusion and Detection. California: Sage Publishers. 
38. Rothstein, H. and Whaley, B., eds. 2013. Art and Science of Military Deception. Boston: Artech House.

39. Scoboria, A. 2013. 'Encouraging and clarifying "Don't Know" responses enhance interview quality'. In Journal of Experimental Applied Psychology, 19 (1), 72-82.

40. Scollon, R. and Scollon, S. 2003. Discourses in Place: Language in the Material World. London: Routledge.

41. Sidnell, J. 2010. 'The design and positioning of questions in inquiry testimony'. In Freed, A. and Ehrlich, S., eds. 2010. "Why Do You Ask?" The Function of Questions in Institutional Discourse. Oxford University Press.

42. Stokoe, E. 2010. "'I'm not gonna hit a lady": conversation analysis, membership categorization and man's denial of violence towards women'. In Discourse and Society, 21 (1), 59- 82. Los Angeles: Sage Publications.

43. Stokoe, E. and Edwards, D. 2008. "'Did you have permission to smash you neighbor's door?" Silly questions and their answers in policesuspect interrogations'. In Discourse Studies, 10 (1), 89- 111.

44. Whaley, B. 1982. 'Toward a general theory of deception'. In Journal of Strategic Studies, (5), 178- 192.

45. Williamson, T. 1993. 'From interrogation to investigative interviewing: strategic trends in police questioning'. In Journal of Community and Applied Social Psychology, 27, 73- 84.

46. Wodak, R. 1995. 'Critical linguistics and critical discourse analysis'. In Handbook of Pragmatics Manual, 3, 204- 210. John Benjamins Publishing Company.

47. Yule, G. 2007. The Study of Language. Cambridge: Cambridge University Press. 